\section{Pendampingan keselamatan dan kesehatan kerja petugas sampah di Desa Tamanharjo, Singosari Malang}

\author{
Yoyok Bekti Prasetyo', Rahmad Wijaya', dan Joko Susilo'
}

\section{Altruis}

\begin{abstract}
Garbage workers are very at risk of accidents at work. The work environment of the waste officer when handling garbage in the trash can which has a lot of sharp and dangerous objects, bringing various types of diseases. Efforts are needed to assist waste officers. This assistance is carried out by providing health education about the risks and dangers of the diseases that can be experienced by waste officers while working. This assistance is a promotive and preventive effort aimed at waste officers to avoid health problems or occupational diseases. Most of the work accidents experienced by garbage officers were due to mechanical factors such as being scratched, stabbed, and slipping (71.4\%). Another accident was twisted and a falling by $42.9 \%$ for each. Meanwhile, for occupational diseases, musculoskeletal problems (pain in the waist muscles) and the presence of conflict were higher, namely $42.9 \%$ compared to diarrhea and itching of the skin, namely $14.3 \%$. Health education on occupational safety and health for waste officers is effective in increasing the knowledge of waste officers about the risks of their work environment.
\end{abstract}

\section{Keywords}

mentoring, occupational safety and health, waste officer

\section{Pendahuluan}

Petugas sampah merupakan aset berharga untuk menjaga kebersihan lingkungan. Petugas sampah sangat beresiko terjadi kecelakaan kerja. Kecelakaan kerja adalah suatu kejadian yang tidak diduga semula dan tidak dikehendaki, yang mengacaukan proses yang telah diatur dari suatu aktivitas dan dapat menimbulkan kerugian baik korban manusia maupun harta benda. Risiko terjadinya kecelakaan berupa tergores dan tertusuk dimungkinkan karena sampah yang dikelola oleh pekerja mengandung benda tajam, seperti paku, tusuk sate dan pecahan kaca sehingga apabila pekerja tidak hati-hati dan tidak menggunakan alat pelindung diri maka sangat dimungkinkan tergores atau tertusuk benda-benda tersebut (Alma et al., 2019). Dengan demikian, para petugas sampah ini mempunyai potensi risiko yang cukup besar dalam pekerjaannya saat mengambil sampah dari rumah tangga. Beberapa contoh lain yang juga dapat memberikan risiko tersebut antara lain pecahan kaca dan tepian kaleng yang tidak terpotong dengan aman (Rimantho, 2015).

Peluang terjadinya kecelakaan yang sering dialami oleh pekerja yaitu tergores dan jatuh, masing masing sebesar $58 \%$, terpeleset $(50 \%)$ dan tertusuk benda tajam (47\%). Sedangkan peluang terjadinya penyakit yang paling sering dialami pekerja sebagian besar yaitu diare dan gastrointestinal (58\%). Gangguan kesehatan yang paling banyak dialami petugas sampah adalah batuk-batuk sebanyak $98 \%$, sedangkan gejala gangguan kesehatan yang paling sedikit adalah sesak napas sebanyak 55\% (Singga, 2014).

Petugas pengumpul sampah seringkali mengalami cedera akibat sampah yang ditanganinya pada saat melaksanakan tugasnya. Berdasarkan data dari Departemen Tenaga Kerja Trans Pusat Jakarta, kasus cedera akibat kerja di Indonesia termasuk akibat bekerja mengumpulkan sampah dari bulan Januari sampai dengan September 2003 tercatat 81.169 kasus atau setiap harinya rata- rata terjadi lebih dari 300 kasus (Adnani, 2013). Meningkatnya kecelakaan kerja antara lain disebabkan karena kondisi lingkungan kerja yang tidak sehat dan tidak aman. Resiko bahaya lingkungan kerja petugas sampah adalah ketika menjamah sampah di tempat sampah yang banyak bendabenda runcing dan berbahaya, membawa berbagai jenis penyakit, menimbulkan polusi, menyumbat saluran air dan berbagai akibat negatif lainnya (Adnani, 2013).

Kondisi petugas sampah di Desa Tamanharjo berjumlah delapan orang. Petugas sampah setiap hari mengangkut sampah dari tong sampah rumah tangga untuk dibuang

\footnotetext{
${ }^{1}$ Universitas Muhammadiyah Malang

Korespondensi:

Yoyok Bekti Prasetyo, Fakultas IImu Kesehatan Universitas Muhammadiyah Malang

Email: yoyok@umm.ac.id
} 
Tabel 1. Persentase Masalah Kesehatan

\begin{tabular}{ll}
\hline Kategori masalah kesehatan & Persentase \\
\hline Kecelakaan kerja & \\
Tergores & $71.4 \%$ \\
Tertusuk & $71.4 \%$ \\
Terpelintir & $42.9 \%$ \\
Terpeleset & $71.4 \%$ \\
$\quad$ Jatuh & $42.9 \%$ \\
Penyakit akibat kerja & \\
$\quad$ Diare & $14.3 \%$ \\
$\quad$ Gatal - gatal pada kulit & $14.3 \%$ \\
$\quad$ Nyeri pada otot pinggang & $42.9 \%$ \\
$\quad$ Konflik & $42.9 \%$ \\
\hline
\end{tabular}

di tempat pembuangan akhir sampah dengan metode gerobak. Beban kerja petugas sampah di Desa Tamanharjo dengan prediksi jumlah penduduk tahun 2013 sebesar 7.143 jiwa adalah 2,35 1/o/h X $7143=16.786$ liter $/$ hari atau 16,786 kubik (setara dengan 3 truk sampah/hari) (Nigiana et al., 2018; Sodikin, 2015). Tentu saja jumlah ini makin meningkat dari tahun ke tahun. Para petugas sampah juga terlihat tidak menggunakan alat pelindung diri yang memadai saat bertugas mengangkut sampah. Hal ini terjadi karena keterbatasan fasilitas dan juga perilaku yang tidak terbiasa. Melihat hal ini maka diperlukan suatu program pengabdian masyarakat berupa pendampingan keselamatan dan kesehatan petugas sampah.

\section{Metode}

\section{Karakteristik petugas sampah}

Karakteristik petugas sampah berupa: usia, lama kerja, jam kerja/hari, dan tingkat pendidikan. Usia petugas sampah rata-rata 56 tahun. Lama kerja rata-rata 5.17 tahun, dengan rata-rata jam kerja/hari adalah 9.40 jam. Sementara itu tingkat pendidikan petugas sampah sebagian besar adalah lulusan sekolah dasar $(57,1 \%)$ dan sisanya lulusan SMA $(42.9 \%)$.

\section{Riwayat kecelakaan dan penyakit akibat kerja}

Riwaya kecelakaan dan penyakit akibat kerja dari petugas sampah meliputi trauma atau kecelakaan akibat kerja (seperti: tertusuk, tergores, terpeleset, dan jatuh) sedangkan penyakit akibat kerja (seperti: diare, adanya ketegangan psikologis seperti konflik).

Tabel 1 menunjukkan bahwa kecelakaan kerja yang pernah dialami petugas sampah sebagian besar karena faktor mekanik seperti tergores, tertusuk, dan terpeleset (71.4\%). Kecelakaan yang lain adalah terpelintir dan jatuh sebanyak $42.9 \%$. Sedangkan untuk penyakit akibat kerja masalah pada muskuloskeletal (nyeri pada otot pinggang) dan adanya konflik lebih tinggi yaitu $42.9 \%$ dibandingkan dengan diare dan gatal-gatal pada kulit yaitu $14.3 \%$.

\section{Peningkatan pengetahuan petugas sampah}

Peningkatan pengatahuan petugas sampah diukur dengan kuesioner yang terdiri dari sepuluh item pernyataan. Pengukuran dilakukan dua kali pretest dan post-test. Hasil menunjukkan adanya peningkatan nilai rata-rata petugas sampah dalam menjawab soal dari 44.29 saat pretest menjadi 51.43 saat post-test. Sedangkan range nilainya adalah 20-80 saat pretest dan 40 - 70 saat post-test.

\section{Diskusi \\ Hubungan antara kecelakaan kerja dengan usia, lama kerja, dan tingkat pendidikan}

Kecelakaan kerja sangat dipengaruhi oleh usia, lama kerja, jam kerja/hari, dan tingkat pendidikan. Usia mempunyai pengaruh yang penting terhadap kejadian kecelakaan akibat kerja. Golongan usia tua mempunyai kecenderungan yang lebih tinggi untuk mengalami kecelakaan akibat kerja dibandingkan dengan golongan usia muda karena usia muda mempunyai reaksi dan kegesitan yang lebih tinggi. Namun usia muda pun sering pula mengalami kasus kecelakaan akibat kerja, hal ini mungkin karena kecerobohan dan sikap suka tergesa-gesa. Pekerja muda usia biasanya kurang berpengalaman dalam pekerjaannya, lebih kurang perhatian, kurang disiplin, dan cenderung menuruti kata hati.

Umum mengetahui bahwa beberapa kapasitas fisik, seperti penglihatan, pendengaran dan kecepatan reaksi, menurun sesudah usia 30 tahun atau lebih. Sebaliknya mereka lebih berhati-hati, lebih dapat dipercaya dan lebih menyadari akan bahaya dari pada tenaga kerja usia muda. Efek menjadi tua terhadap terjadinya kecelakaan masih terus ditelaah. Namun terdapat kecenderungan bahwa beberapa jenis kecelakaan seperti terjatuh lebih sering terjadi pada tenaga kerja usia 30 tahun atau lebih dari pada tenaga kerja berusia sedang atau muda. Juga angka beratnya kecelakaan rata-rata lebih meningkat mengikuti pertambahan usia.

Pengalaman kerja merupakan faktor yang dapat mempengaruhi terjadinya kecelakaan akibat kerja. Masa kerja berhubungan langsung dengan pengalaman kerja. Masa kerja dapat dikategorikan menjadi: Masa kerja baru ( 6 tahun); Masa kerja sedang (6-10 tahun); dan Masa kerja lama (¿10 tahun). Berdasarkan berbagai penelitian dengan meningginya pengalaman dan keterampilan akan disertai dengan penurunan angka kecelakaan akibat kerja.

Kewaspadaan terhadap kecelakaan akibat kerja bertambah baik sejalan dengan pertambahan usia dan lamanya kerja di tempat kerja yang bersangkutan. Tenaga kerja baru biasanya belum mengetahui secara mendalam seluk-beluk pekerjaannya. Kewaspadaan terhadap kecelakaan akibat kerja bertambah baik sejalan dengan pertambahan usia dan lamanya kerja di tempat kerja yang bersangkutan.

Pendidikan seseorang berpengaruh dalam pola pikir seseorang dalam menghadapi pekerjaan yang dipercayakan kepadanya, selain itu pendidikan juga akan mempengaruhi 
tingkat penyerapan terhadap pelatihan yang diberikan dalam rangka melaksanakan pekerjaan dan keselamatan kerja. Pendidikan adalah segala upaya yang direncanakan untuk mempengaruhi orang lain baik individu, kelompok atau masyarakat sehingga mereka melakukan apa yang diharapkan oleh pelaku pendidikan. Semakin tinggi tingkat pendidikan seseorang, maka mereka cenderung untuk menghindari potensi bahaya yang dapat menyebabkan terjadinya kecelakaan.

Hubungan tingkat pendidikan dengan lapangan pekerjaan yang tersedia bahwa pekerja dengan tingkat pendidikan rendah, seperti Sekolah Dasar atau bahkan tidak pernah bersekolah akan bekerja di lapangan yang mengandalkan fisik. Hal ini dapat mempengaruhi terjadinya kecelakaan kerja karena beban fisik yang berat dan dapat mengakibatkan kelelahan yang merupakan salah satu faktor yang mempengaruhi terjadinya kecelakaan akibat kerja (Triwibowo \& Pusphandani, 2012).

\section{Riwayat kecelakaan dan penyakit akibat kerja}

Riwayat kecelakan kerja sebagian besar karena faktor mekanik (tertusuk, tergores, jatuh). Hal ini diakibatkan lingkungan kerja petugas sampah adalah ketika menjamah sampah di tempat sampah yang banyak benda-benda runcing dan berbahaya. Gerakan mekanis ini dapat menimbulkan cedera atau kerusakan seperti tersayat, terjepit, terpotong, atau terkelupas. Dampak lainnya adalah masalah muskuloskeletal. Resiko gangguan muskuloskeletal sering terjadi pada petugas sampah dikarenakan saat mengangkat dan memindahkan sampah dari bak sampah ke alat transportasi yang digunakan. Prevalensi cedera pada pekerja pengumpul sampah lebih besar dari pekerja kantor. Hal ini disebabkan karena selama proses pengumpulan sampah, bagian-bagian tubuh yang paling rentan mengalami risiko muskuloskeletal adalah punggung, lengan dan kaki. Hal ini juga sesuai dengan sebuah penelitian para pekerja pengumpul sampah di Taiwan yang menunjukkan bahwa keluhan muskuloskeletal terjadi dua kali lebih tinggi daripada pekerja yang bekerja di kantor, terutama pada bagian tubuh pinggang, siku dan pergelangan tangan (Rimantho, 2015).

\section{Kesimpulan}

Petugas sampah merupakan pahlawan kebersihan yang harus diperhatikan keselamatan dan kesehatannya. Salah satu upaya promotif dan preventif yang bisa dilakukan adalah memberikan pendidikan kesehatan. Pendidikan kesehatan tentang keselamatan dan kesehatan kerja pada petugas sampah yang diberikan terbukti efektif dalam meningkatkan pengetahuan petugas sampah. Pengetahuan yang meningkat ini diharapkan selaras dengan penggunaan alat pelindung diri. Penggunaan alat pelindung diri bagi petugas sampah merupakan upaya pencegahan dari bahaya berupa kecelakaan dan penyakit akibat kerja.

\section{Referensi}

Adnani, H. (2013). Perilaku petugas pengumpul sampah untuk melindungi dirinya dari penyakit bawaan sampah di wilayah Patangpuluhan Yogyakarta tahun 2009. Kes Mas: Jurnal Fakultas Kesehatan Masyarakat, 4(3), 144-152. https://doi.org/10.12928/kesmas.v4i3.1089

Alma, L. R., Ulfah, N. H., Utomo, Y., Afifah, A., Adawiyah, U., Kholifah, W. D. N., \& Merillarosa, I. (2019). Analisis risiko bahaya pada pekerja di tempat penampungan sampah terpadu reduce reuse recycle (Tpst 3R) Mulyoagung Bersatu Dau Kabupaten Malang. Preventia: The Indonesian Journal of Public Health, 4(2), 110. https://doi.org/10.17977/um044v4i2p110-115

Nigiana, J., Larasati, E., \& Widowati, N. (2018). Manajemen pengelolaan sampah di Kecamatan Tembalang. Journal of Materials Processing Technology, 1(1), 1-8. https://doi.org/10.14710/jppmr.v5i1.10421

Rimantho, D. (2015). Identifikasi risiko kesehatan dan keselamatan kerja pada pekerja pengumpul sampah manual di Jakarta Selatan. Jurnal Optimasi Sistem Industri, 14, 1-15. https://doi.org/10.25077/josi.v14.n1.p1-15.2015

Singga, S. (2014). Gangguan kesehatan pada pemulung di TPA Alak Kota Kupang. Jurnal MKMI, 30-35. https://journal.unhas.ac.id/index.php/mkmi/article/view/475/289

Sodikin, S. (2015). Arahan dan manajemen pengangkutan sampah di Kecamatan Pondok Gede Kota Bekasi. SOSIO DIDAKTIKA: Social Science Education Journal, 2(1), 50-57. https://doi.org/10.15408/sd.v2i1.1410

Triwibowo, C., \& Pusphandani, M. E. (2013). Kesehatan Lingkungan dan K3. Jakarta: Litbang Kemenkes RI 